\title{
Investigation of Teachers' Self-Efficacy Beliefs, Locus of Control and Intercultural Sensitivities from the Perspective of Individual Differences
}

\author{
Figen Akca $^{1}$, Emrah Ulutas ${ }^{1} \&$ Cemile Yabanci ${ }^{1}$ \\ ${ }^{1}$ Faculty of Education, Uludag University, Bursa, Turkey \\ Correspondence: Emrah Ulutas, Osmaneli Primary School, Bilecik, Turkey. Tel: 90-553-491-7807.
}

Received: February 19, 2018 Accepted: March 18, 2018 Online Published: March 22, 2018

doi:10.5539/jel.v7n3p219 URL: https://doi.org/10.5539/jel.v7n3p219

\begin{abstract}
The purpose of this study is to examine the correlation between Teachers' Self-efficacy beliefs, locus of control and intercultural sensitivities and to analyze these variables based on various demographic variables. The data of the study were collected through teachers' locus of control scale developed by Sadowski, Taylor, Woodward, Peacher, \& Martin (1982) adopted into Turkish by Buluş (2011), teachers' self-efficacy beliefs scale developed by Dellinger, Bobbett, Olivier, \& Ellet (2008) adopted into Turkish by Taşkın \& Haciömeroglu (2010) and Intercultural Sensitivity scale developed by Chen \& Starosta (2000) adopted into Turkish by Bulduk, Tosun, \& Ardıç (2011). The research is a descriptive study in relational screening model. 237 volunteer teachers who worked in different schools all of which are in the city of Bursa participated in the research. According to the results of the research, the self-efficacy beliefs of the teachers participating in the research differ significantly from the variables studied in the scope of the research according to the branch and seniority variables. The intercultural sensitivity of the teachers differed significantly only according to the seniority variable. It has been determined that the level of locus of control of teachers is not significantly different from the variables studied in the scope of the research. It was determined that there was a statistically significant relationship between teachers' self-efficacy beliefs; intercultural sensitivity and locus of control levels. It was also found that self-efficacy beliefs and intercultural sensitivity variables together account for $30 \%$ of change in locus of control.
\end{abstract}

Keywords: self-efficacy belief, locus of control, intercultural sensitivity

\section{Introduction}

To be successful in education, all elements of education must have the highest quality. Teachers, one of the most important among the many elements of education, are supposed to have the quality of teaching profession and field knowledge, observing national, moral and universal values, carrying out the teaching and learning process effectively (MEB, 2017). As well as having such qualities, in order to have success in education, teachers are expected to have the belief that they are able to do this.

Looking at the self-efficacy beliefs of teachers in order to understand how much they have in this regard, in terms of its importance, has been one of the most studied topics in recent years. Self-efficacy; is one of the concepts of Social Learning Theory and is defined as the judge of self about the capacity of the individual to organize the activities required for the individual to exhibit a certain performance (Zimmerman, 1995). Bandura (1995) argues that what is believed to be true, rather than the reality itself, is more effective in human behavior (as cited in Seçkin \& Başbay, 2013). When people perceive their competences less than it actually is, this causes them to use less of their capacities. However, higher perceptions often have a positive effect on their performances (Tschannen-Moran, Hoy, \& Hoy, 1998).

Self-efficacy beliefs also affect people's emotional reactions and thinking styles. Individuals with high self-efficacy beliefs can be more calm and productive when faced with challenging work. Individuals with lower self-efficacy beliefs are more anxious because they perceive their work to be more difficult than it actually is, and healthier thinking also becomes more difficult. Thus, self-efficacy beliefs affect people's achievements quite significantly (Pajares, 2002; as cited in Seçkin \& Başbay, 2013). It is understood that the concept of self-efficacy is one of the important variables for success in the teaching profession. Teachers are expected to have high self-efficacy perceptions in order to optimize their capacities during the education process. Teacher self-efficacy 
perception can be defined as the belief that a teacher can improve his / her students in all aspects to the desired level (Özata, 2007).

Why do some teachers have a more positive attitude towards education than other teachers, even though almost every teacher has many problems in the educational environment? Among many reasons, one of the most important reasons is the teachers' self-efficacy beliefs (Rimm-Kaufman \& Sawyer, 2004; as cited in Çapri \& Kan, 2006). Pajares (1992; as cited in Yılmaz \& Çokluk Bökeoğlu, 2008) states that teachers with high proficiency beliefs are more open to try new approaches in the educational process, have more close relationships with their students, and their students take more responsibility in learning process. Self-efficacy beliefs contribute to the acquisition of important information in terms of the training of advanced teachers with problem solving abilities, and with the desire and self-sacrifice that teachers can fulfill (Taşkın \& Hacıömeroğlu, 2010).

Many researches have been carried out on the self-efficacy perceptions of teacher and teacher candidates in our country and abroad. In these surveys; the self-efficacy perceptions of teachers were evaluated by Gençtürk \& Memiş (2010) in terms of job satisfaction of teachers; by Saracaloğlu \& Dinçer (2009) in terms of academic motivation; by Kafkas, Açak, Çoban, \& Karademir (2010) in terms of occupational anxiety; by Altunçekiç, Yaman, \& Koray (2005) in terms of problem solving skills; by Akgün (2013), in terms of web pedagogical content information; by Güvenç (2011) in terms of investigated student achievement responsibility perceptions variables. Ekici (2008) in his study; examines the effects of the classroom management course on self-efficacy perceptions of teacher candidates. Taşkın \& Haciömeroğlu (2010), Cerit (2010), Korkut \& Babaoğlan (2012), Yeşilyurt (2013), Seçkin \& Başbay (2013) have examined the self-efficacy beliefs about teaching in terms of various demographic variables.

Tschannen-Moran \& Woolfolk Hoy (2001) investigate the relationship between teachers' self-efficacy beliefs, teacher's locus of control, and student responsibility for achievement in their research. In the study conducted by Kahyaoğlu \& Yangın (2007), the self-efficacy levels of teacher candidates regarding the teaching profession were examined in terms of demographic variables. Gürol, Altunbaş, \& Karaaslan (2011) examined the self-efficacy beliefs and epistemological beliefs of prospective teachers in terms of variables such as gender, department, and graduated high school type. Demirtaş, Cömert, \& Özer (2011) examined the relationship between self-efficacy perceptions and attitudes towards the teaching profession while studying self-efficacy perceptions of teacher candidates over various variables.

As one of the other variables of the research, the concept of locus of control appears, for the first time, in social learning theory, like the concept of self-efficacy perception. Rotter (1966) is the first researcher to define the locus of control within social learning theory as internal and external control. According to Rotter (1990), the internal locus of control can be defined as the responsibility of one's own behavior and attitude as a result of one's behavior. External controls the responsibility of someone else's behavior, or chance and destiny.

Internally controlled people believe that the events they experience are under their control and that their lives can be shaped in the direction of their will. When they are unsuccessful, they take responsibility rather than externalizing the causes. At the same time, they value their own thoughts and beliefs. Without being influenced by the pressures of the outside they can live in accordance with their own beliefs and thoughts. Outside controlled people, on the other hand, are often more accommodating to the layout of the circle they live in. Their behaviors are determined by the thought of "What do others say?" and the effects of external pressures on their behavior are greater (Cüceloğlu, 1993). Internally controlled people are much better at accessing and using information than external controlled people (Phares, 1976; as cited in Kılınç, 2012), because they are able to find a variety of options to solve their problems when they encounter a problem (K1lınç, 2012). In this respect, the concept of locus of control can provide important information in terms of educating teachers who can take responsibility for their behavior while fulfilling the requirements of the teaching profession and can move their own dynamics into problem solving.

Many researches have been carried out in our country and abroad, examining the locus of control of teachers and prospective teachers. In these surveys, the relation between teacher locus of control and some variables was studied. Those variations were Ören (1991), self-acceptance; Pişkin (1996), self esteem; Onur (2003), attitudes and self-esteem towards learning foreign languages; Başol \& Türkoğlu (2009), thinking styles; Buluş (2011), goal orientation and academic achievement; Kılınç (2012), levels of intimidation; Soycan Ertürk (2012); perceptions of organizational trust; Tümkaya (2000) and Sürgen (2014), burnout levels. Rotter (1966) also examined the internal and external locus of control in terms of widespread expectations. 
According to Ören (1991) studies internally controlled individuals have a higher rate of self-acceptance and the belief that they are accepted by other people when compared to externally controlled individuals. They also have a higher level of belief in their ability to succeed in solving problems and a higher level of taking responsibility for their behavior.

Culture is the transmission of common purposes, values, identities and important values that are formed as a result of the common experiences of the members in the community. Multiculturalism is a combination of cultural values such as language, religion, gender, age, race, ethnicity (APA, 2002). The concept of multiculturalism has emerged as an approach that supports the assumptions of a constructivist approach which is influenced by the thoughts of post modernity (D'andrea, 2000; Siviş, 2002).

Cultural sensitivity has become one of the important issues for healthy social interaction in communities with cultural diversity. Cultural sensitivity is a concept which relates to the positive emotional nourishment such as curiosity, recognition, and sympathy for other cultures for an individual (Chen, 1997; as cited in Aydın \& Şahin, 2017).

In schools which have different cultural characteristics together, teachers and students with different cultural characteristics are in interactions the education continues. In these environments, negativities can arise due to cultural differences. The important thing is to maintain an understanding of education in which different cultures are taken into consideration. The most important task at this point is undertaken by teachers. Teacher; who applies the training program, carries out evaluation work and forms the learning environment (Polat, 2009; Rengi \& Polat, 2014).

There are various researches aiming at the importance of cultural sensitivity in education (Üstün, 2011; Y1lmaz \& Göçen, 2013; Rengi, 2014; Rengi \& Polat; 2014, Öksüz \& Baba Öztürk, 2016; Demir \& Üstün, 2017; Onur Sezer \& Bağçeli Kahraman, 2017) Yılmaz \& Göçen (2013) investigated the intercultural sensitivities of primary school teacher candidates according to demographic variables. According to the results of the study, while the intercultural sensitivity levels of teacher candidates showed a significant difference in terms of education type variable, they did not show any significant difference in terms of gender, class level and placement unit variables.

Üstün (2011) conducted a survey to determine the variables that could influence teacher candidates' levels of ethnocentrism and cross-cultural sensitivity. According to the results of the research, it was found that there was a statistically significant difference between the levels of intercultural sensitivity of the prospective teachers and the high school types they graduated, the department they were educated in, and also the experiences and friendship status from different cultures or countries.

Saracaloğlu, Yenice, \& Özden (2013) found that there was a positive relationship between the self-efficacy of the teacher candidates and the internal locus of control; negative and significant relationship between the self-efficacy of the teacher candidates and the external locus of control in the researches examining the self-efficacy perception and the locus of control together. Yenice, Evren, \& Özden (2012) have found that there is no significant relationship between teacher candidates' academic locus of control and self-efficacy perceptions in their research. Güvenç's (2011) research used the concept of responsibility perception that meets locus of control. As a result of the research, positive correlations were found between teacher candidates 'self-efficacy perceptions and students' perceptions of responsibility.

There are some studies in our country and abroad that examine self-efficacy beliefs, locus of control and cross-cultural sensitivity in terms of various variables. Teacher self-efficacy belief in these researches is examined in terms of variables like job satisfaction (Gençtürk \& Memiş, 2010); academic self-efficacy (Tabancalı ve Çelik, 2013); academic motivation (Saracaloglu \& Dinçer, 2009); attitudes towards the teaching profession (Demirtaş et al., 2011); occupational concern (Kafkas et al., 2010) and problem solving skills (Altunçekiç, Yaman, \& Koray, 2005). Teacher locus of controls examined in terms of variables like self-esteem (Pişkin, 1996; Onur, 2003); goal orientation, academic achievement (Buluş, 2011); burnout level (Tümkaya, 2000; Sürgen, 2014); thinking styles (Başol \& Türkoğlu, 2009); organizational trust perception (Soycan Ertürk, 2012) and some demographic variables (Yılmaz \& Göçen, 2013). Intercultural sensitivity levels are examined in terms of variables like ethnocentrism (Üstün, 2011; Demir \& Üstün, 2017); conflict action styles (Öksüz \& Baba Öztürk, 2016); attitudes towards multicultural education (Onur Sezer \& Bağçeli Kahraman, 2017) and perceptions of cultural differences (Rengi, 2014; Rengi \& Polat, 2014).

There is a limited number of studies on the relationship between teacher self-efficacy beliefs and locus of control in our country and abroad (Saracaloğlu et al., 2013; Güvenç, 2011; Yenice et al., 2012; Tschannen-Moran \& Woolfolk Hoy, 2001). No study could be found, investigating their relationship with intercultural sensitivity. 
Nowadays, teachers are required to train individuals with high self-efficacy beliefs, sensitive to internally controlled and sensitive to different cultures, it is expected that prospective teachers who will train them must carry these traits. Therefore, it can be said that this study is important in terms of determining the level to which teachers carry these characteristics and the relationship between self-efficacy perceptions, locus of control and intercultural sensitivities. Besides, this study will also contribute to writing on the field. The aim of this study is to examine the relationship between self-efficacy beliefs, locus of control and the intercultural sensitivities of the teachers working in the schools and also examine these variables according to some demographic variables.

For this purpose responses are searched for these questions:

1) Do the teachers' self-efficacy beliefs, intercultural sensitivity and locus of control levels differ according to variables such as gender, age, branch, seniority, longest living place, longest living area, living in a different culture or not, and having a second mother tongue or not?

2) Is there a meaningful relationship between teachers' self-efficacy beliefs, intercultural sensitivity and locus of control?

3) Are the intercultural sensitivity and self-efficacy beliefs of the teachers predicting locus of control levels?

\section{Method}

\subsection{Research Model}

This study examines the relationship between teachers' self-efficacy beliefs level, intercultural sensitivity and locus of control levels in the relational screening model. The screening model is a research model aimed at describing what is happening now or in the past without changing a situation. The relational screening model is a screening model aimed at determining the severity and degree of change in two or more variables (Karasar, 2002).

\subsection{The Study Group}

In this survey, the study group is consisted of 237 teachers working in different schools in the city of Bursa. Demographic information of the study group is given in table 1.

As seen in the table, the study group consisted of 237 teachers (166 (70\%) female, $71(30 \%)$ male). It is observed that the number of female teachers participating in the research is intense. When we look at the age variable, $6 \%$ of teachers are $20-25$ years, $21 \%$ are $26-30$ years, $23 \%$ are $31-35$ years, $12 \%$ are $36-40$ and $38 \%$ are 40 and over. Teachers seem to be showing an agglomeration in age groups of 40 and over. When we look at the seniority variable, $25 \%$ of teachers are in $1-5$ years, $18 \%$ are $6-10$ years, $18 \%$ are $11-15$ years and $40 \%$ are 16 and above. Teachers appear to have accumulated in groups of 16 and over. When we look at the longest living place variable, $60 \%$ of teachers are in metropolitan, $19 \%$ in province, $23 \%$ in district and $6 \%$ in village group. It is seen that the rate of teachers living in the metropolitan area is considerably higher than the other groups. $55 \%$ of the teachers are Marmara, 13\% are Aegean, 3\% are Eastern Anatolia, 20\% are Central Anatolia, 2\% are Southeastern Anatolia, 4\% are Black Sea and 3\% it belongs to the Mediterranean region group. It is seen that about half of the teachers who participated in the research spent most of their lives in the Marmara Region. When we looked at the variable of living in a different culture, $12 \%$ of the teachers answered yes and $88 \%$ answered no. When we look at the data, it is seen that there are quite a number of teachers who answered no to the variable of living in a different culture. When we look at the variance of having a second mother tongue, $5 \%$ of teachers say yes, $95 \%$ give no answer. A large majority of teachers do not seem to have a second mother tongue. When we look at the branch variable; $27 \%$ of the teachers are primary school teachers, $11 \%$ are English teachers, $10 \%$ are mathematics teachers, $10 \%$ are Turkish-literate teachers and $7 \%$ are science teachers (physics, chemistry, biology and science teachers), $9 \%$ are pre-school teachers, $11 \%$ are social science teachers (philosophy, geography, history, psychology and social studies teaching), $8 \%$ are religious teaching groups (religion and occupational religious courses teaching ), and $9 \%$ of them are from the branches of occupational courses (clothing technologies, folk dances, office management, information technologies, electricity, drama teaching). When we look at the data, it is seen that the teachers who come from the branch of primary school teacher are concentrated. 
Table 1. Frequency and percentage distributions of demographic characteristics of teachers participating in the survey

\begin{tabular}{|c|c|c|c|c|}
\hline & Category & & $\mathrm{f}$ & $\%$ \\
\hline \multirow[t]{3}{*}{ Gender } & Female & & 166 & 70.0 \\
\hline & Male & & 71 & 30.0 \\
\hline & & Total & 237 & 100.0 \\
\hline \multirow[t]{6}{*}{ Age } & $20-25$ & & 14 & 5.9 \\
\hline & $26-30$ & & 49 & 20.7 \\
\hline & $31-35$ & & 55 & 23.2 \\
\hline & $36-40$ & & 29 & 12.2 \\
\hline & 41- above & & 90 & 38.0 \\
\hline & & Total & 237 & 100.0 \\
\hline \multirow[t]{5}{*}{ Seniority } & $1-5$ year & & 58 & 24.5 \\
\hline & $6-10$ year & & 43 & 18.1 \\
\hline & $11-15$ year & & 42 & 17.7 \\
\hline & 16 - above & & 94 & 39.7 \\
\hline & & Total & 237 & 100.0 \\
\hline \multirow[t]{10}{*}{ Branch } & Primary school Teacher & & 63 & 26.6 \\
\hline & English Teacher & & 25 & 10.5 \\
\hline & Mathematics Teacher & & 23 & 9.7 \\
\hline & Turkish-Literature Teaching & & 23 & 9.7 \\
\hline & Science Teacher & & 17 & 7.2 \\
\hline & Pre-School Teacher & & 22 & 9.3 \\
\hline & Social Science Teacher & & 25 & 10.5 \\
\hline & Religion Teaching & & 18 & 7.6 \\
\hline & Occupational Courses Teaching & & 21 & 8.9 \\
\hline & & Total & 237 & 100.0 \\
\hline \multirow[t]{5}{*}{ Longest Living Place } & Metropolitan & & 123 & 51.9 \\
\hline & Province & & 46 & 19.4 \\
\hline & District & & 55 & 23.2 \\
\hline & Village & & 13 & 5.5 \\
\hline & & Total & 237 & 100.0 \\
\hline \multirow[t]{9}{*}{ Longest Living Region } & Marmara & & 131 & 55.3 \\
\hline & Aegean & & 30 & 12.7 \\
\hline & Eastern Anatolia & & 7 & 3.0 \\
\hline & Central Anatolia & & 48 & 20.3 \\
\hline & Southeastern Anatolia & & 5 & 2.1 \\
\hline & Black Sea & & 10 & 4.2 \\
\hline & Mediterranean & & 6 & 2.5 \\
\hline & Abroad & & 0 & 0 \\
\hline & & Total & 237 & 100.0 \\
\hline \multirow[t]{3}{*}{ Situation of Living in a Different Culture } & Yes & & 28 & 11.8 \\
\hline & No & & 209 & 88.2 \\
\hline & & Total & 237 & 100.0 \\
\hline \multirow[t]{3}{*}{ Having a Second Mother Tongue } & Yes & & 12 & 5.1 \\
\hline & No & & 225 & 94.9 \\
\hline & & Total & 237 & 100.0 \\
\hline
\end{tabular}

\subsection{Research Instrument}

\subsubsection{Teacher Self-Efficacy Belief Scale}

The scale was developed by Dellinger, Bobbett, Olivier, \& Ellet (2008) and Turkish version was done by Taşkın \& Hacıömeroğlu (2010). The correlation coefficient of Pearson's product in the adaptation process of the scale was $r=0.710$ and $(p=0.001)$. The KMO value and the Barlett Globality Test were calculated for validity studies. At the end of the analysis, the BMD value was determined as 0.942 and the Barlett test was found to be significant. It was understood that the basic components had a 5 -factor structure consisting of positive dimension of the scale, effective learning-teaching process, planning and learning development, academic development and individual differences according to the factor analysis result. However, the main components were factor 
analysis and the 22nd and 23th items, which had a factor load value of less than 0.30 and did not fit the scale, were removed from the scale.

In the adaptation study, the Cronbach Alpha value for all of the scale was calculated as 0.950 . Analyzes indicate that the Teacher Self-Efficacy Scale is a valid and reliable scale (Taşkın \& Haciömeroğlu, 2010). The Cronbach Alpha value of the scale was found to be .95 in this study.

\subsubsection{Teacher Locus of Control Scale}

The Teacher Control Room Scale was developed by Sadowski, Taylor, Woodward, Peacher, \& Martin (1982) to measure the locus of control in teachers according to Rotter's conceptualization. It was adapted to Turkish by the Buluş (2011). It is a graded, 5-Likert-type scale, consisting of 20 items, ranging from Totally Participating (1) to Never Participating (5). As the score on the scale increases, the internal locus of control level also increases.

The Cronbach's alpha (a) coefficient was found to be .80 in the internal consistency reliability analysis of the scale. As the alpha coefficient increased when two items with the lowest item-test correlation were subtracted from the scale, the 9th and 11th items, which were lower than the item-test correlation of 20, were removed from the scale and reanalyzed and the alpha coefficient increased to .82 . It can be said that the substance-test correlations obtained in this direction and the reliability coefficient of the scale are high enough (Buluş, 2011).

When the factor structure of the scale was analyzed by base-components method over 18 items, it was understood that the items 2, 3,13 and 17 were not loaded in the first dimension, and these four items were also removed from the scale and the number of items in the measure was reduced to 14. In this case, the scale of your scale is changed to be the lowest 14 and the highest 70 . Findings indicate that the Teacher Locus of Control Scale is a reliable and valid tool for Turkish teacher candidates and teachers (Buluş, 2011). In this study, the Cronbach Alpha scale was found to be .81 .

\subsubsection{Intercultural Sensitivity Scale}

The "Intercultural Sensitivity Scale" developed by Chen \& Starosta (2000) was adapted to Turkish by Bulduk, Tosun \& Ardıç (2011). There are 24 items, 9 of them have negative and 15 of them have positive content. Options range from Totally Agree (1) to Never (5). It is understood that the cross-cultural sensitivities of teachers increase as the sum of the answered scores increases.

The alpha reliability coefficient of the intercultural sensitivity scale was found to be 0.72 . This result shows that your scale is reliable enough. In this study, the Cronbach Alpha value of the scale was found to be .88 . In addition, the scale consists of 5 sub-dimensions named as respect to cultural differences, intercultural interaction participation, enjoyment of intercultural interaction, self-confidence in intercultural interaction, and care in intercultural interaction (Bulduk et al., 2011).

Through the personal information form, prepared for taking demographic information of the participants, information regarding gender, age, seniority, branch, longest living place, longest living region, situation of living in a different culture and having a second mother tongue was taken from teachers.

Applications were made by the researchers after the volunteer teachers were informed about the purpose of researching at appropriate times outside of the class hours, then the scales were distributed and given adequate time and retrieved.

For the analysis of the data, SPSS 22.0 program was used. Normalization tests have been performed to determine appropriate analytical techniques prior to the analysis, and it has been found that normal distribution of data is appropriate. Parametric analysis methods are used because the data show normal distribution.

While analyzing, T-test and one-way analysis of variance (ANOVA) were used for unrelated samples to look at the differences in teacher self-efficacy belief, intercultural sensitivity, and locus of control levels according to demographic variables. Pearson simple linear correlation analysis was used to determine the relationship between self-efficacy beliefs, intercultural sensitivity, and locus of control. Finally, multiple linear regression analysis was used to determine the effect of intercultural sensitivity, locus of control, and self-efficacy belief levels on each other.

\section{Results}

In this section, findings and interpretations related to the analysis of collected data are presented in order to find answers to the questions that are asked in accordance with the objectives of the research. 
3.1 Findings Related to Gender, Age, Seniority, Branch, Longest Living Place, Longest Living Region, Living Status in a Different Culture and Having a Second Mother Tongue at the Level of Self-Efficacy Belief

As a result of the T-test to determine whether the self-efficacy beliefs of the teachers participating in the research differ according to gender, living in a different culture and having a second mother tongue, there was no significant difference between the mean scores obtained ( $p>.05)$. When we look at the results; it can be said that these variables have no meaningful effect on teachers' self-efficacy beliefs.

As a result of one-way analysis of variance (ANOVA) conducted to determine whether the self-efficacy beliefs of the teachers participating in the research differ according to age, longest living place and the longest living region variables; there was no significant difference between the mean scores obtained $(p>.05)$. When we look at the results; it can be said that these variables have no meaningful effect on teachers' self-efficacy beliefs.

The results of the one-way analysis of variance (ANOVA) on whether the self-efficacy beliefs of the teachers participating in the study differ significantly according to the branch variable are given in Table 2.

Table 2. The results of One-way Analysis of Variance (ANOVA) concerning teachers' self-efficacy belief points according to teachers' branch variables

\begin{tabular}{lcccccl}
\hline Source of Variance & $\begin{array}{c}\text { Sum of } \\
\text { squares }\end{array}$ & sd & $\begin{array}{l}\text { Average } \\
\text { of Squares }\end{array}$ & $\mathrm{F}$ & $\mathrm{p}$ & Significant Difference \\
\hline Intergroup & 4.231 & 8 & 0.529 & 2.677 & 0.008 & $\begin{array}{l}\text { Math./Pre school- } \\
\text { Math./Occupational }\end{array}$ \\
Inside group & 45.048 & 228 & 0.198 & & & \\
Total & 49.279 & 236 & & & & \\
\hline
\end{tabular}

In order to test whether there is a significant difference between the self-efficacy belief levels of 237 teachers from nine different branches, the averages of the self-efficacy belief scores obtained from the teacher self-efficacy belief scale were compared with unidirectional variance analysis for unrelated samples. As a result of the test; it was found that there was a significant difference between the average of the teachers from the primary school teaching group $(\overline{\mathrm{X}}=3.34)$, the average of the teachers from the English teaching group $(\overline{\mathrm{X}}=$ $3.23)$, the average of the teachers from the mathematics group $(\bar{X}=3.06)$, the average of the teachers from the Turkish- literature teaching group $(\overline{\mathrm{X}}=3.28)$, the average of the teachers from the science group $(\overline{\mathrm{X}}=3.27)$, the average of the teachers from the group of pre-school teachers $(\overline{\mathrm{X}}=3.5)$, the average of the teachers from the social science group $(\bar{X}=3.13)$, the average of the teachers from the religious courses group $(\bar{X}=3.25)$, the average of the teachers from the occupational courses group $(\bar{X}=3.52)$. $[F(8.228)=2.677, p<.05]$. As a result of the Tukey multiple comparison test, it was found that there was a significant difference between the teachers coming from the branch of mathematics teaching and the scores of the teachers coming from the branch of pre-school and occupational courses.

The results of one-way analysis of variance (ANOVA) on whether the self-efficacy beliefs of the teachers participating in the research differ significantly from the seniority variable are given in Table 3.

Table 3. The results of One-way Analysis of Variance (ANOVA) concerning teachers' self-efficacy belief points according to teachers' seniority variable

\begin{tabular}{lllllll}
\hline Source of Variance & $\begin{array}{l}\text { Sum of } \\
\text { squares }\end{array}$ & sd & $\begin{array}{l}\text { Average } \\
\text { Of Squares }\end{array}$ & F & p & $\begin{array}{l}\text { Significant } \\
\text { Difference }\end{array}$ \\
\hline Intergroup & 1.700 & 3 & 0.567 & 2.775 & 0.042 & $1-5$ Year/16-More \\
Inside group & 47.579 & 233 & 0.204 & & & \\
Total & 49.279 & 236 & & & & \\
\hline
\end{tabular}

In order to test whether there is a significant difference between the self-efficacy belief levels of 237 teachers from four different seniority groups, the averages of the self-efficacy belief scores obtained from the teacher self-efficacy belief scale were compared with the one-way variance analysis for unrelated samples. As a result of the test; a significant difference was found between the average of the teachers from the year group of 1-5 years $(\overline{\mathrm{X}}=3.17)$, the average of the teachers from the group of 6-10 years $(\overline{\mathrm{X}}=3.33)$, the average of the teachers from 
the group of 11-15 years $(\overline{\mathrm{X}}=3.24)$, and the average of the teachers from the group of 16 and up $(\overline{\mathrm{X}}=3.29)$. [F (3. $233)=2.775, p<.05]$. As a result of the Tukey multiple comparison test, it was found that the significant difference was between the scores of the teachers who worked for 1-5 years and the teachers who worked for 16 years or more.

3.2 Findings Related to the Differences Between Gender, Age, Seniority, Branch, Longest Living Place, Longest Living Region, Living in a Different Culture, and Having a Second Mother Tongue at Intercultural Sensitivity Level

As a result of the T-test to determine whether the intercultural sensitivity levels of the teachers participating in the research differ according to gender, living in a different culture and having a second mother tongue, there was no significant difference between the mean scores obtained ( $p>.05)$. When we look at the results; it can be said that the mentioned variables have no meaningful effect on the intercultural sensitivity levels of the teachers.

One way analysis of variance (ANOVA) was conducted to determine whether the intercultural sensitivity levels of the teachers participating in the study differ according to age, branch, longest living place and longest living region variables. There was no significant difference between the mean scores obtained ( $p>.05)$. When we look at the results; it can be said that the mentioned variables have no meaningful effect on the intercultural sensitivity levels of the teachers.

As a result of one-way analysis of variance for seniority variable, it was found that there was a meaningful difference between the averages for intercultural sensitivity levels. The results of one-way analysis of variance (ANOVA) on whether teachers' intercultural sensitivity differ significantly from seniority variable are given in Table 4.

Table 4. The results of One-way Analysis of Variance (ANOVA) concerning teachers' intercultural sensitivity points according to teachers' seniority variable

\begin{tabular}{lllllll}
\hline Source of Variance & $\begin{array}{l}\text { Sum of } \\
\text { squares }\end{array}$ & sd & $\begin{array}{l}\text { Average } \\
\text { Of Squares }\end{array}$ & F & p & $\begin{array}{l}\text { Significant } \\
\text { Difference }\end{array}$ \\
\hline Intergroup & 1.971 & 3 & 0.657 & 3.025 & 0.030 & $1-5 / 11-15$ 1-5/16-More \\
Inside group & 50.605 & 233 & 0.217 & & & \\
Total & 52.576 & 236 & & & & \\
\hline
\end{tabular}

In order to test whether there is a significant difference between the levels of intercultural sensitivity of 237 teachers from four different seniority groups, the averages of the intercultural sensitivity scores obtained from the teacher intercultural sensitivity scale were compared with the unidirectional variance analysis for unrelated samples. As a result of the test; It is found that there is a significant difference between The average of the teachers from the group of $1-5$ years $(\overline{\mathrm{X}}=4.25)$, the average of the teachers from the group of 6-10 years $(\overline{\mathrm{X}}=$ 4.23), the average of the teachers from the group of 11-15 years $(\bar{X}=4.06)$ the average of the teachers from the group of 16 and above years $(\overline{\mathrm{X}}=4.06)$. [F $(3.233)=3.025, \mathrm{p}<.05]$. As a result of the Tukey multiple comparison test, it was seen that the scores of the teachers who worked between 1-5 years showed a significant difference when compared to the scores of the teachers who worked between the years 11-15 and 16-more years.

\subsection{Findings Related to the Differences Between Gender, Age, Seniority, Branch, Longest Living Place, Longest} Living Region, Living in a Different Culture, and Having a Second Mother Tongue at Locus of Control Level

As a result of the T-test to determine whether the locus of control levels of the teachers participating in the research differ according to gender, living in a different culture and having a second mother tongue, there was no significant difference between the mean scores obtained ( $>.05)$. When we look at the results; it can be said that these variables have no meaningful effect on teachers' level of locus of control and intercultural sensitivity.

One way analysis of variance (ANOVA) was conducted to determine whether the locus of control levels of teachers participating in the study differ according to age, branch, seniority, longest living place and the longest living region variables. There was no significant difference between the mean scores obtained $(\mathrm{p}>.05)$. When we look at the results; it can be said that these variables have no meaningful effect on teachers' level of locus of control and intercultural sensitivity.

\subsection{Findings Related to the Relation Between Self-Efficacy Belief, Locus of Control and Cultural Sensitivity}

The results of a simple linear correlation analysis for determining the relationship between self-efficacy beliefs and intercultural sensitivity and locus of control level of teachers participating in the research are given in Table 5 . 
Table 5. Correlations between the points taken from teacher self-efficacy beliefs, cultural sensibility and locus of control scales (Pearson test)

\begin{tabular}{|c|c|c|c|}
\hline & Self-efficacy Beliefs & Cultural Sensibility & Locus Of Control \\
\hline Self-efficacy Beliefs & & 1 & \\
\hline Cultural Sensibility & $.321^{* *}$ & 1 & \\
\hline Locus of control & $.447^{* *}$ & $.436^{* *}$ & 1 \\
\hline
\end{tabular}

The relationship between self-efficacy beliefs and intercultural sensitivity levels of teachers was analyzed by simple linear correlation and it was found that there was a positive correlation between self-efficacy belief and intercultural sensitivity $(r=0.321, p<.01)$. From this result it can be concluded that individuals with high levels of intercultural sensitivity have higher self-efficacy beliefs than those with low levels of intercultural sensitivity.

The simple linear correlation process which was used to determine whether there is a relationship between teachers' self-efficacy beliefs and locus of control levels shows that there is a positive and significant relationship between self-efficacy beliefs and locus of control $(\mathrm{r}=0.447, \mathrm{p}<.01)$. As a result, it can be concluded that the self-efficacy beliefs of the individuals with high locus of control level are higher than those with low self-efficacy belief level.

The simple linear correlation process to find out whether there is a relationship between the levels of intercultural sensitivity of teachers and the level of locus of control indicates that there is a positive correlation between the level of intercultural sensitivity and the level of locus of control in the positive direction $(r=0.436$, $\mathrm{p}<.01)$. As a result of this, it can be concluded that the level of intercultural sensitivity is higher with the individuals having high level of locus of control than individuals having low level of locus of control.

\subsection{Findings Related to the Contribution That Self-Efficacy Beliefs and Intercultural Sensitivity Makes to the Prediction of Locus of Control}

The results of the multiple linear regression analysis conducted to show how self-efficacy beliefs and intercultural sensitivity levels of the teachers participating in the research predict the locus of control is given in Table 6 .

Table 6. Standard multiple regression analysis results regarding the predicting locus of control point

\begin{tabular}{lcllllll}
\hline Variable & $\mathrm{B}$ & $\begin{array}{l}\text { Standard } \\
\text { Error }\end{array}$ & $\mathrm{\beta}$ & $\mathrm{t}$ & $\mathrm{p}$ & $\begin{array}{l}\text { Dual } \\
\mathrm{r}\end{array}$ & $\begin{array}{l}\text { Partial } \\
\mathrm{r}\end{array}$ \\
\hline Constant & 1.489 & 0.275 & - & 5.421 & 0.000 & - & - \\
Self-efficacy belief & 0.376 & 0.064 & 0.342 & 5.904 & 0.000 & 0.447 & 0.360 \\
Intercultural Sensitivity & 0.347 & 0.062 & 0.326 & 5.632 & 0.000 & 0.436 & 0.346 \\
$\mathrm{R}=0.543$ & $\mathrm{R}^{2}=0.295$ & & & & & & \\
$\mathrm{~F}_{(2,234)=49.030}$ & $\mathrm{P}=0.000$ & & & & & & \\
\hline
\end{tabular}

As a result of the multiple linear regression analysis conducted to determine how variables such as self-efficacy beliefs and intercultural sensitivity (they are thought to have an effect on locus of control) predicts the focus control, self-efficacy beliefs and cross-cultural susceptibility variables together show a significant relationship $\left(\mathrm{R}=0.543, \mathrm{R}^{2}=0.295\right)$ with cross-cultural susceptibility. The two variables, together, account for $30 \%$ of the change in locus of control.

According to the standardized regression coefficients, the order of relative importance which predictive variables have on the locus of control is that; self-efficacy belief $(\beta=0.342)$ and intercultural sensitivity $(\beta=0.326)$. When regression coefficients of significance tests are taken into consideration, it is seen that intercultural sensitivity ( $p$ $<.01)$ and self-efficacy belief $(\mathrm{p}<.01)$ are significant predictors of locus of control.

\section{Conclusion and Discussion}

This study which examines the relationship between teachers' self-efficacy beliefs, cultural sensitivity and locus of control was found to have a positive relationship in the positive direction. This finding is important in terms of having the same characteristics of these three variables, which play an important role in the quality of education of teachers working in the field. When locus of control and self-efficacy beliefs are considered as the personality traits, they are found to be related with each other according to results of some studies (Saracaloglu et al., 2013; Güvenç, 2011; Yenice et al., 2012; Tschannen-Moran \& Woolfolk Hoy, 2001). Cultural sensitivity has taken its 
place among the study subjects in the last decade as the concept of cultural personality in the literature. The concept of multicultural personality was first dealt with by Van Der Zee \& Van Oudenhoven (2000). It is a combination of flexibility, openness, cultural empathy, social enterprise and emotional balance. In this case, the fact that the concept of culture personality has entered the list of affective characteristics such as self-efficacy and locus of control supports the findings of this study. When studying the field literature, there were no studies investigating the relationship between these three variables. Findings obtained in this sense are very valuable in terms of literature.

Another finding of the study is that teachers' levels of intercultural sensitivity and self-efficacy beliefs are found to be predicting the locus of control levels. As a result of the multiple linear regression analysis, self-efficacy beliefs and intercultural sensitivity variables together account for $30 \%$ of the locus of control. It is known that the acquisition of the concept of the locus of control, which was put forward by Rotter for the first time, carries experiential entities (Rotter, 1966). For this reason, it is inevitable that the traits of self-efficacy and cultural sensitivity that develop as a result of education processes and also in family, have influence on the development of the locus of control.

As a result of the analysis of whether the self-efficacy beliefs of the teachers showed significant differences according to the branch variable, it was found that the significant difference was found between the teachers coming from the mathematics teacher branch and the teachers coming from the branch of pre-school and vocational teacher education branches. It is seen that pre-school and vocational courses teachers have a higher self-efficacy level than mathematics and science teachers when the results of the self-efficacy scale are taken into consideration. When the literature is examined in this respect, researches reveal that the self-efficacy perceptions of the teacher candidates differ significantly according to the type of program they are studying (Çapri \& Çelikkaleli, 2008; Erişen \& Çeliköz, 2003; Şeker, Deniz, \& Görgen, 2005; Yeşilyurt, 2013). On the other hand, Kahyaoğlu \& Yangın (2007) and Saracaloglu et al. (2013) investigated the self-efficacy perceptions of the teacher candidates in their researches and found that the branch variable did not make any difference.

The lack of a difference in the level of cultural sensitivity of teachers according to age, gender and branch variables can be interpreted as promising. In the past, in many studies, cultural sensitivity was mostly explained by the characteristics of female gender (Endress \& Lueck, 1998; Inoue \& Johnson, 2000; Demir, 2012). In the same way, there was a tendency to believe that relativist approach to cultural differences was part of the female-specific relativist view. However, nowadays there are researches that show that cultural sensitivity is not related to gender (Üstün, 2011; Polat \& Barka, 2014; Y1lmaz \& Göçen, 2013). On the other hand, there are researches that show that the cultural sensitivities of the teachers do not differ according to the education level (Tortop, 2014; Onur Sezer \& Bağçeli Kahraman, 2017). This result can be thought to be the effect of the teachers' education faculties on similar programs.

It has been determined that there is no significant difference between the self-efficacy and intercultural sensitivity levels of the teachers participating in the research according to the variables of living in a different culture, the longest living place, the longest living region and having a second mother tongue. This finding is also very significant when it is thought that the multicultural predisposition is more influenced by the environment and culture in which the individual lives. The fact that the working group comes from the Marmara region, which receives a big deal of migration, requires that they contact cultural differences in their surroundings. This will in time require cultural differences to be perceived as a normal and harmonious situation, not an irrational one. In this sense, it is also natural that cultural sensitivities have turned into a kind of personality characteristic of teachers who grew up in a region where differences are thought as natural beginning from their birth.

The difference between the level of self-efficacy beliefs and the level of intercultural sensitivities according to seniority years in the study was examined and it was concluded that 16 years and older workers differed significantly from the newly-started teachers. With the increase in the level of experience and knowledge, it is anticipated that a more relativist viewpoint will be gained from an ethnocentric viewpoint to cultural differences. When the literature is examined, it has been found that studies on self-efficacy levels and cultural sensitivities of teachers have similar results with respect to seniority (Rengi \& Polat, 2014; Demircioğlu \& Özdemir, 2014; Yiğittir \& Adem, 2011; Polat, 2012).

Overall, the following recommendations can be reached;

There is almost no correlation between the cultural sensitivity levels of teacher candidates, self-efficacy perceptions and academic control centers, so it would be meaningful to look at the relationships between these three variables using larger sample groups. 
Larger samples and qualitative studies can be applied in the sense that there is a significant relationship between teachers' cultural sensitivity, self-efficacy and locus of controls and that the predictors of locus of control are largely (30\%) supporting two other variables.

Findings in the form of increasing cultural sensitivities as teachers increase in seniority suggest that priority should be given to in-service training in favor of raising cultural awareness for new teachers, without waiting for the seniority years.

Teachers' cultural sensitivity, locus of control and self-efficacy perceptions can also be examined with other emotional variables such as, meta-cognitive abilities, critical thinking features, epistemological beliefs, self-regulation skills, and so on.

This study is limited to 237 teachers working in city of Bursa from Marmara region, and the scales of "Intercultural Sensitivity Scale", "Teacher Self-Efficacy Belief Scale" and "Teacher Focus Control Scale".

\section{References}

Akgün, F. (2013). Öğretmen adaylarının web pedagojik içerik bilgileri ve öğretmen öz-yeterlik algıları ile ilişkisi. Trakya Üniversitesi Eğitim Fakültesi Dergisi, 3(1), 48-58.

Altunçekiç, A., Yaman, S., \& Koray, O. (2005). Öğretmen adaylarının öz yeterlik inanç düzeyleri ve problem çözme becerileri üzerine bir araştırma (Kastamonu ili örneği). Kastamonu Eğitim Dergisi, 13(1), 93-102.

Aydın, Ş., \& Şahin, M. (2017). Psikolojik danışman adaylarında kültürel duyarlılığı yordayan bazı değişkenler. Buca Eğitim Fakültesi Dergisi, 43, 64-77.

Başol, G., \& Türkoğlu, E. (2009).Sınıf öğretmeni adaylarının düşünme stilleri ile kontrol odağı durumları arasındaki ilişki. Uluslararası İnsan Bilimleri Dergisi, 6(1), 732-757.

Bulduk S., Tosun H., \& Ardıç E. (2011). Türkçe kültürler arası duyarlılık ölçeğinin hemşirelik öğrencilerinde ölçümsel özellikleri. Türkiye Klinikleri J Med Ethics, 19(1), 25-31.

Buluş, M. (2011). Öğretmen adaylarında bireysel farkl1lıklar perspektifinden amaç yönelimleri, denetim odağı ve akademik başarı. Kuram ve Uygulamada Eğitim Bilimleri, 11(2), 529-546.

Çapri, B., \& Çelikkaleli, Ö. (2008). Öğretmen adaylarının öğretmenliğe ilişkin tutum ve mesleki yeterlik inançlarının cinsiyet, program ve fakültelerine göre incelenmesi. İönü Üniversitesi Eğitim Fakültesi Dergisi, 9(15), 33-53.

Çapri, B., \& Kan, A. (2006). Öğretmen kişilerarası öz-yeterlik ölçeğinin Türkçe formunun geçerlik ve güvenirlik çalışması. Mersin Üniversitesi Eğitim Fakültesi Dergisi, 2(1), 48-61.

Cerit, Y. (2010). Öğretmen öz-yeterlik ölçeğinin geçerlik ve güvenirlik çalışması ve sınıf öğretmeni adaylarının öz yeterlik inançları. Ĕgitimde Kuram ve Uygulama, 6(1), 68-85.

Chen, G. M., \& Starosta, W. J. (2000). The development and validation of the intercultural sensitivity scale. Human Communication, 3, 1-15.

Cüceloğlu, D. (1993). Insan ve davranışı. İstanbul: Remzi.

D'Andrea, M. (2000). Postmodernism, constructivism and multiculturalism: Three forces reshaping and expanding our thoughts about counseling. Journal of Mental Health Counseling, 22(1), 1-17.

Dellinger, A. B., Bobbett, J. J., Olivier, D. F., \& Ellet C. D. (2008). Measuring teachers self efficacy beliefs: Development and use of the TEBS-Self. Teaching and Teacher Education, 24(3), 751-766. https://doi.org/10.1016/j.tate.2007.02.010

Demir, S. (2012). Çok kültürlü eğitimin Erciyes Üniversitesi öğretim elemanları için önem derecesi. International Periodical for the Languages, Literature and History of Turkish or Turkic, 7(4), 1453-1475.

Demir, S., \& Üstün, E. (2017). Öğretmen adaylarının kültürlerarası duyarlılık ve etnik merkezcilik düzeylerinin çeşitli değişkenler açısından incelenmesi. YYÜ Eğitim Fakültesi Dergisi, 14(1), 182-2014.

Demircioğlu, E., \& Özdemir, M. (2014). Pedagojik formasyon öğrencilerinin çok kültürlü eğitime yönelik tutumlarının bazı değişkenlere göre incelenmesi. Ege Eğitim Dergisi, 15(1), 211-232. https://doi.org/10.12984/eed.22924

Demirtaş, H., Cömert, M., \& Özer, N. (2011). Öğretmen Adaylarının Öz yeterlik İnançları ve Öğretmenlik Mesleğine İlişkin Tutumları. Eğitim ve Bilim, 36(159), 96-111. 
Ekici, G. (2008). Sınıf yönetimi dersinin öğretmen adaylarının öğretmen öz yeterlik algı düzeyine etkisi. Hacettepe Üniversitesi Ĕ̈itim Fakültesi Dergisi, 35, 98-110.

Endres, K. L., \& Lueck, T. L. (1998). A new instrument to measure diversity in the curriculum. Journalism \& Mass Communication Educator, 53(1), 85-94. https://doi.org/10.1177/107769589805300110

Erişen, Y., \& Çeliköz, N. (2003). Öğretmen adaylarının öğretmenlik davranışları açısından kendilerine yönelik yeterlilik algıları. Türk Ĕ̈itim Bilimleri Dergisi, 1(4), 427-439.

Gençtürk, A., \& Memiş, A. (2010). İlköğretim okulu öğretmenlerinin öz yeterlik algıları ve işdoyumlarının demografik faktörler acısından incelenmesi. İlköğretim Online, 9(3), 1037-1054.

Gürol, A., Altunbaş, S., \& Karaaslan, N. (2011). Öğretmen adaylarının öz yeterlik inançları ve epistemolojik inançları üzerine bir çalışma. E-Journal of New World Sciences Academy, Education Sciences, 5(3), 1395-1404.

Güvenç, H. (2011). Öğretmen adayı öğrencilerin mesleki öz yeterlilik algıları ile öğrenci başarısı sorumluluk algilar1. E-Journal of New World Sciences Academy Education Sciences, 6(2), 1410-1421.

Inoue, Y., \& Johnson, K. (2000). Diversity and Multiculturalism in Higher Education: University of Guam. Paper presented at the 22nd Annual National Association for Asian and pacific American Education Conference on Reaching Across Cultures in the New Millennium, Kailua-Kona, Hawaii, April 11-15.

Kafkas, M. E., Açak, M., Çoban, B., \& Karademir, T. (2010). Beden Eğitimi Öğretmen Adaylarının Öz-Yeterlik Algıları İle Mesleki Kaygıları Arasındaki İlişki. İnönü Üniversitesi Eğitim Fakültesi Dergisi, 11(2), 93-111.

Kahyaoğlu, M., \& ve Yangın, S. (2007). İlköğretim öğretmen adaylarının mesleki öz-yeterliklerine ilişkin görüşleri. Kastamonu Ĕ̈itim Dergisi, 15(1), 73-84.

Karasar, N. (2002). Bilimsel araştırma yöntemi. Ankara: Nobel Yayınları.

Kılınç, A. Ç. (2012). Öğretmenlerin denetim odağı puanları ile yıldırma yaşama düzeyleri arasındaki ilişki. Türk Eğitim Bilimleri Dergisi, 10(4), 805-835.

Korkut, K., \& Babaoğlan, E. (2012). Sınıf öğretmenlerinin öz yeterlik inançları. Uluslararası Yönetim İktisat ve Isşletme Dergisi, 8(16), 2012.

Milli, E. B. (2017). Öğretmenlik mesleği genel yeterlikleri. Retrieved from http://oygm.meb.gov.tr/meb_iys_dosyalar/2017_12/11115355_YYRETMENLYK_MESLEYY_GENEL_Y ETERLYKLERY.pdf

Öksüz, Y., \& Baba Öztürk, M. (2016). Öğretmen adaylarının çatışma eylem stilleri ile kültürlerarası duyarlılık düzeyleri arasındaki ilişki. Manas Sosyal Araştırmalar Dergisi, 5(4), 1-12.

Onur Sezer, G., \& Bağçeli Kahraman, P. (2017). Sınıf ve Okul Öncesi Öğretmen Adaylarının Çok kültürlü Eğitime Yönelik Tutumları ile Kültürlerarası Duyarlılıkları Arasındaki İlişki: Uludağ Üniversitesi Örneği. Mersin Üniversitesi Eğitim Fakültesi Dergisi, 13(2), 550-560. https://doi.org/10.17860/mersinefd.336742

Onur, M. (2003). Üniversite öğrencilerinin yabancı dil başarısının yabancı dil öğrenmeye ilişkin tutum, özsaygı ve denetim odağı açısından incelenmesi. Yayımlanmamış Doktora Tezi. Atatürk Üniversitesi, Erzurum.

Ören, N. (1991). Denetim odağı ve kendini kabul arasındaki ilişkiler. Psikolojik Danışma ve Rehberlik Dergisi, $1(2), 20-28$.

Özata, H. (2007). Öğretmenlerin Öz-Yeterlik Algılarının Ve Örgütsel Yenileşmeye İlişkin Görüşlerinin Araştırılması. Kocaeli Üniversitesi Sosyal Bilimler Enstitüsü, Yüksek Lisans Tezi.

Pişkin, M. (1996). Self-esteem and locus of control of secondary school children both in England and Turkey (Unpublished doctoral dissertation). Leicester University, England.

Polat, S. (2009). Öğretmen adaylarının çok kültürlü eğitime yönelik kişilik özellikleri. International Online Journal of Educational Sciences, 1(1), 154-164.

Polat, S. (2012). Okul müdürlerinin çok kültürlülüğe ilişkin tutumları. Hacettepe Üniversitesi Eğitim Fakültesi Dergisi, 42, 334-343.

Polat, S., \& Barka, T. O. (2014). Preservice teachers' intercultural competence: A comparative study of teachers in Switzerland and Turkey. Eurasian Journal of Educational Research, 54, 19-38. https://doi.org/10.14689/ejer.2014.54.2 
Rengi, Ö. (2014). Sınıf öğretmenlerinin kültürel farklılık algıları ve kültürler arası duyarlılıkları. Yayımlanmamış Yüksek Lisans Tezi. Kocaeli Üniversitesi, Kocaeli.

Rengi, Ö., \& Polat, S. (2014). Sınıf öğretmenlerinin kültürel farklılık algıları ve kültürler arası duyarlılıkları. Journal of World of Turks, 6(3), 135-156.

Rotter, J. B. (1966). Generalized expectancies for internal versus external control of reinforcement. Psychological Monographs, 80, 1-28. https://doi.org/10.1037/h0092976

Rotter, J. B. (1990). Internal versus external control of reinforcement. American Psychologist, 45(4), 489-493. https://doi.org/10.1037/0003-066X.45.4.489

Sadowski, C. J., Taylor, R. C., Woodward, H. R., Peacher, R. K., \& Martin, B. J. (1982). The reliability and validity of a Likert type locus of control scale for teachers. JSAS Catalog of Selected Documents in Psychology, 12, 32. (Ms. No. 2475).

Saracaloğlu, A. S., \& Dinçer, B. (2009). A study on correlation between self-efficacy and academic motivation of prospective teachers. Procedia Social and Behavioral Sciences, 1, 320-325. https://doi.org/10.1016/j.sbspro.2009.01.060

Saracaloğlu, A. S., Yenice, N., \& Özden, B. (2013). Fen Bilgisi, Sosyal Bilgiler ve sınıf öğretmeni adaylarının öğretmen öz-yeterlik algılarının ve akademik kontrol odaklarının incelenmesi. Pamukkale Üniversitesi Eğitim Fakültesi Dergisi, 34(2), 227-250. http://dx.doi.org/10.9779/PUJE555

Seçkin, A., \& Başbay, B. (2013). Beden eğitimi ve spor öğretmeni adaylarının öğretmenlik mesleğine ilişkin özyeterlik inançlarının incelenmesi. International Periodical for the Languages, Literature and History of Turkish or Turkic, 8(8), 253-270.

Şeker, H., Deniz, S., \& Görgen, W. (2005). Tezsiz yüksek lisans öğretmen adaylarının öğretmenlik yeterlikleri üzerine değerlendirmeleri, Kuram ve Uygulamada Eğitim Yönetimi Dergisi, 42, 237-253.

Siviş, R. (2002). Yapılandırmacı yaklaşım ve Türkiye'de psikolojik danışma alanındaki uygulanabilirliği. Türk Psikolojik Danışma ve Rehberlik Dergisi, 17(2), 43-48.

Soycan Ertürk, Z. B. (2012). Ankara ili genel lise öğretmenlerinin örgütsel güven algıları ve denetim odağı ile ilişkisi. Yayınlanmamış yüksek lisans tezi. Ankara Üniversitesi, Ankara.

Sürgen, S. (2014). Sınıf öğretmenlerinin denetim odağı eğitimleri ile tükenmişlik düzeyleri arasındaki ilişki. Yayınlanmamış yüksek lisans tezi. Balıkesir Üniversitesi, Balıkesir.

Tabancalı, E., \& Çelik, K. (2013). Öğretmen adaylarının akademik öz-yeterlikleri ile öğretmen öz-yeterlilikleri arasındaki ilişki. International Journal of Human Sciences, 10(1), 1167-1184.

Taşkın, Ç. Ş., \& Hacıömeroğlu, G. (2010). Öğretmen öz yeterlik inanç ölçeğinin Türkçe’ ye uyarlanması ve sınıf öğretmeni adaylarının öz yeterlik inançları. Dokuz Eylül Üniversitesi Buca Eğitim Fakültesi Dergisi, 27, 63-75.

Tortop, H. S. (2014). Öğretmen adaylarının üstün yetenekli ve çok kültürlü eğitime ilişkin tutumları. Üstün Yetenekliler Eğitimi ve Araştırmaları Dergisi (UYAD), 2(2), 16-26.

Tschannen-Moran, M., \& Woolfolk Hoy, A. (2001). Teacher efficacy: Capturing an elusive construct. Teaching and Teacher Education, 17, 783-805. https://doi.org/10.1016/S0742-051X(01)00036-1

Tschannen-Moran, M., Hoy, A. W., \& Hoy, W. K. (1998). Teacher efficacy: Its meaning and measure. Review of Educational Research, 68(2), 202-248. https://doi.org/10.3102/00346543068002202

Tümkaya, S. (2000). İlkokul öğretmenlerindeki denetim odağı ve tükenmişlikle ilişkisi. PAÜ Eğitim Fakültesi Dergisi, 8, 1-7.

Üstün, E. (2011). Öğretmen Adaylarının Kültürlerarası Duyarlılık ve Etnik Merkezcilik Düzeylerini Etkileyen Etmenler. Yayımlanmamış Yüksek Lisans Tezi, Yıldız Teknik Üniversitesi.

Van der Zee, K. I., \& Van Oudenhoven, J. P. (2000). The multicultural personality questionnaire: A multidimensional instrument for multicultural effectiveness. European Journal of Personality, 14, 291-309. https://doi.org/10.1002/1099-0984(200007/08)14:4<291::AID-PER377>3.0.CO;2-6

Yenice, N., Evren, B., \& Özden, B. (2012). Relation ship between self-efficacy perceptions of science teacher candidates and academic control focus. Procedia- Socialand Behavioral Sciences, 46, 4044-4049. https://doi.org/10.1016/j.sbspro.2012.06.194 
Yeşilyurt, E. (2013). Öğretmen adaylarının öğretmen öz-yeterlik algıları. Elektronik Sosyal Bilimler Dergisi, 12(45), 88-104.

Yiğittir, S., \& Adem, Ö. C. A. L. (2011). Lise tarih öğretmenlerinin değerler ve değerler eğitimi konusundaki görüşleri. Karamanoğlu Mehmetbey Üniversitesi Sosyal ve Ekonomik Araştırmalar Dergisi, 2011(1), $117-124$.

Yılmaz, F., \& Göçen, S. (2013). Sınıf Öğretmeni Adaylarının Kültürlerarası Duyarlılık Hakkındaki Görüşlerinin Farklı Değişkenlere Göre İncelenmesi. Adıyaman Üniversitesi Sosyal Bilimler Enstitüsü Dergisi, 6(15), 374-392.

Yılmaz, K., \& Çokluk-Bökeoğlu, Ö. (2008). İlköğretim okulu öğretmenlerinin yeterlik inançları. Ankara Üniversitesi Ĕ̈itim Bilimleri Fakültesi Dergisi, 41(2), 143-167.

Zimmerman, B. J. (1995). Self-efficacy and educational development. In A. Bandura (Ed.), Self Efficacy in Changing Societies (pp. 46-68). New York: Cambridge University Press. https://doi.org/10.1017/CBO9780511527692.009

\section{Copyrights}

Copyright for this article is retained by the author(s), with first publication rights granted to the journal.

This is an open-access article distributed under the terms and conditions of the Creative Commons Attribution license (http://creativecommons.org/licenses/by/4.0/). 